INTERNATIONAL HIGHER EDUCATION, Number 62 Winter 2011

Pages 25-26

Venezuelan Higher Education: The Chavez Revolution

Daniel C. Levy

Daniel C. Levy is SUNY distinguished professor and director of PROPHE, the Program of Research on Private Higher Education, University at Albany. E-mail: DLevy@uamail.albany.edu.

Hugo Chavez's clash with Venezuelan higher education is a vivid present-day example of a history of confrontation between leftist, populist regimes, and higher education in Latin America. Such regimes often regard the existing universities as elitist and thus outside the revolution, while universities often see a dangerous grab for control that restricts their academic freedom. Relations were tense and rocky in the aftermath of the Mexican Revolution of 1910 right up until the 1940s. Peru's leftist military government had a frosty relationship with higher education in the late 1960s. Salvadore Allende's socialist coalition administration faced strong opposition in the early 1970s in Chile, though it also enjoyed strong support. Peronist confrontation with university interests resurfaced in Argentina in the 1970s. Of course the most conspicuous and ongoing example is Cuba, as totalitarianism meant the takeover of higher education by the early 1960s. And, of course, Latin America also has many historical examples of confrontation between rightist regimes (sometimes military) and higher education, but this is not a history to which today's Venezuela attaches itself. 
President since 1998, Chavez has been transforming the country's higher education. Supporters find the changes consistent with Chavez's overall Bolivarian Revolution-socialist, populist, and with a strong indigenous orientation. Critics find the changes consistent with an overall assault on democracy and on academic autonomy and quality. Neither side questions that much has been transformed, notwithstanding that their evaluations of good and bad are diametrically opposed.

Higher education transformation must be seen in the overall context of Venezuela's regime-inspired political and socioeconomic transformation. Chavez policies have split the left both outside and inside the country. Oliver Stone's recent South of the Border documentary film is expansively promotional, whereas democratic socialists internationally have been disenchanted. In foreign affairs the regime, buttressed by oil revenues, is markedly anticapitalist and anti-US government. It has allied itself with countries such as Iran and Syria and naturally with populist-leftist regional counterparts in countries such as Bolivia and Ecuador. It has come close to blows with neighboring Colombia, a close US ally, and allowed refuge for Colombia's armed rebels. In higher education, confrontation with Venezuela's traditionally left-leaning national university (Universidad Central) shows the domestic rift. Student-led opposition speaks of a "third path," against both Chavez and the previously long-standing and ossified elite that Chavez has popularly rejected.

\section{THE UNIVERSIDAD BOLIVARIANA}

The latest chapter in the higher education saga during the Chavez era involves criticism of a new formula for government funding of public higher education. 
The basis for funding will be enrollment size. Why would the rector of the historic national university strongly criticize this approach?-because Chavez has transformed the public sector through creation and expansion of new universities. By decree he established in 2003 the Universidad Bolivariana, which would already have a massive 180,000 student body by 2006 , with a stated target of a million by 2009 (with 190 satellite campuses). Even the 2006 enrollment figure makes the university one of the largest in Latin America. Anything approaching the projected goal would make it by far the largest Latin American university. The university is not only tuition free but also offers open admissions. A lack of tuition has been the norm in the country's public sector (and in Latin America's) and there have been occasional open admissions policies in other countries (e.g., Argentina), but the admissions policy for the Universidad Bolivariana goes further. It also goes markedly further than Venezuela's traditional policy of relative high access by the standards of the region.

The Universidad Bolivariana is part of Chavez's overall "Mission Sucre," using social programs to help the poor, indigenous, and transforming society. Critics perceive in the Bolivariana yet another stroke of political control, whereas the university and its defenders appropriate the opposition's language insofar as they claim to be fostering pluralism and democracy.

\section{Pre-Existing Private And Public Sectors}

As one would expect, Chavez's policies have alienated the country's privatebusiness sector. The regime speaks often of the "public interest" as opposed to "private interests." Private schools at lower educational levels have felt themselves challenged and restricted. In higher education there is strong 
antagonism with private universities. The Santa Rita university has been accused of running illegal programs. In many parts of the world such charges have often led to a denial of accreditation or to probation. However, the Santa Rita has been nationalized in 2010. Santa Rita declares the assault purely political. However, most Venezuelan private universities function with considerable continuity. A degree of private autonomy, even while the public sector is more manipulated, has precedent in the region-as in Argentina under the military in the 1960s and 1970s and Brazil under the military in the mid-1960s.

More striking than Venezuelan private-university continuity is that even the country's public "autonomous" universities have maintained a degree of continuity and autonomy. The large benefits secured over the years-perhaps unsurpassed in Latin America-remain mostly in tack. (Long before the Chavez era, public "experimental" universities were added alongside the "autonomous" universities, partly to create an alternative to them.) One can only speculate on the reasons for Chavez's relatively hands-off approach in regard to the public autonomous universities as well as the private universities. Perhaps Chavez has not wanted to take another step in hardening middle-class opposition.

The recent confrontation with the national university seems to be more about diminishing the autonomous universities' relative weight rather than directly attacking them. These universities are reduced in importance by virtue of the massive growth in the regime-aligned new public universities. Similarly, if the private sector is not directly repressed, it loses relative weight. Just five years ago it accounted for over 40 percent of the nation's total higher education enrollment; now, owing to the massive new public growth, the share is around half that. 
Chavez's present term expires in 2112. Even if he is defeated at the polls (which is in doubt) and leaves power (which is also in doubt) what transpires between now and then? And what ensues after that point? Will the system presently be further transformed? 